DOI https://doi.org/10.18551/rjoas.2021-03.18

\title{
ANALYSIS OF TUNA COMPETITIVENESS OF ACEH PROVINCE (INDONESIA) IN INTER-NATIONAL MARKET
}

\author{
Santri Linda*, Safrida, Zakiah \\ Master's Program of Agribusiness, Faculty of Agriculture, Syiah Kuala University, \\ Banda Aceh, Indonesia \\ *E-mail: lindasantri121@gmail.com
}

\begin{abstract}
Tuna commodities of Aceh Province is one of the export-oriented commodities with the potential of large fishery resources and high demand in the international market this is an opportunity for Aceh Province to become a major producer and exporter of fishery commodities especially tuna. However, based on data obtained from BPS (2019), the number of tuna is exported by Aceh Province is still low and even decrease every year. The purpose of this research is to determine the competitiveness in terms of comparative advantages in tuna in Aceh Province. This study was conducted in Aceh Province using time series data for nine years from 2011 to 2019. The object of the study was frozen and fresh yellowfin tuna. The scope of research is limited to the export value of tuna in Aceh Province, the total export value of Aceh Province, the export value of world tuna and the total value of world exports. The analysis method used in this study was Revealed Comparative Advantage (RCA) method. The results showed that the Aceh Province tuna have strong competitiveness or have comparative advantages in the international market.
\end{abstract}

\section{KEY WORDS}

Tuna fish, competitiveness, RCA.

Aceh is a province that has an area of water reaching 295,370 km2 (Aceh Marine and Fisheries, 2019). The vast marine resources make Aceh Province has excellent fisheries potency, one of them is tuna commodity, and supported by the high demand for tuna in the international market makes Aceh Province has the opportunity to improve the regional economy through the fishery sector and the opportunity to become a major producer and exporter of fishery commodities will be large. However, based on data obtained from BPS (2019), the number of tuna exports in Aceh is very low, in fact it is decrease every year. It is assumed that tuna export declined due to the low competitiveness of tuna exports. According to Suhartanti (2017), the competitiveness of tuna export in Aceh Province is low because there is no quality assurance on the quality of tuna exported. Improper handling of caught tuna and inadequate facilities are the cause of low quality of tuna exort.

In 1980-1990, Aceh had succeeded with the value of oil and gas export are abundant, however along with the decreasing supply of natural gas in Aceh, the value of exports fell sharply. The export value of Aceh has slumped sharply from 962.97 million dollars in 2013 to about 22.87 million dollars in 2016, but slowly increased again until 2019 the export value of Aceh Province reached 166.56 million dollars (BPS, 2019).

FAO Year Book (2009) shows that Indonesia became the second largest producer in the world in the fishery sector in 2012 with the number of Indonesian caught fishery production reached $5,813,800$ tons. Aceh Province is ranked in the top $9^{\text {th }}$ position of the highest production in Indonesia. The following is the breakdown of the average production of the 9 largest tuna producing provinces in Indonesia from 2011 to 2019 (ton).

Based on Figure 1 above, Aceh Province is ranks $9^{\text {th }}$ in terms of Indonesian tuna production, with the amount of production per year is an average of 9,959 $\mathrm{kg}$. The result of tuna production will be marketed in the domestic market as well as in the international market. The destination country for tuna export of Aceh province are Thailand, Japan, Singapore, Malaysia, South Korea and Hong Kong. 


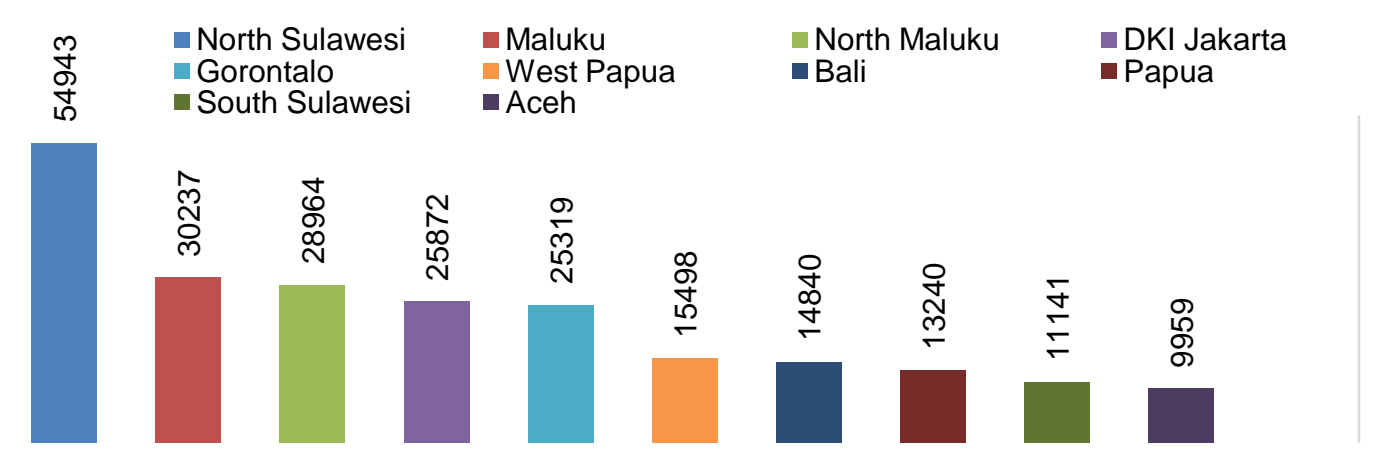

Figure 1 - Average Tuna Production in 9 Largest Provinces in Indonesia (Ton) in 2011 to 2019

The marketing of tuna of Aceh Province in the international market has increased and decreased. However every year Aceh Province always export tuna to foreign markets. This shows that Acehnese tuna have their own competitiveness in the international market. The increase and decrease in tuna exports is strongly influenced by the level of competitiveness of the tuna commodity itself. To increase exports, the tuna export commodity must have a high level of competitiveness. So that, the level of competitiveness of tuna commodity in Aceh Province needs to be known to increase the competitiveness of tuna exports so that it can compete with other countries in the world that also specialize in tuna. Information on the competitiveness of tuna exports will also be a step for the Aceh Provincial government as well as tuna exports to maintain and improve the competitiveness of tuna.

\section{MATERIALS AND METHODS OF RESEARCH}

The collection of data and information about tuna required in the writing of this study was carried out in Aceh Province. The research was conducted with a vulnerable time of nine years, namely from 2011 to 2019 .

The object used in this study is the tuna commodity of Aceh Province. The scope of research is limited to the export value of tuna fish in Aceh Province, the total export value of Aceh Province, the value of world tuna exports and the total value of world exports.

This type of research is descriptive quantitative by using secondary data collected based on 2011to 2019 time series. The data was taken from several sources such as the Central Bereau of Statistics of Aceh Province, the Central Bereau of Statistics of Indonesia, center for statistical and information of Ministry of Marine Affairs and Fisheries, UN Comtrade, Trade Maps and other sources that support and complement each other.

The method used in answering hypotheses is the Revealed Comparative Advantage method. Revealed Comparative Advantage (RCA) is used to measure the competitiveness of tuna in Aceh Province in terms of comparative advantage in the international market. RCA was introduced by Bela Balassa in 1989, whose formula is systematically:

$$
\operatorname{RCA}_{\mathrm{i}}^{\mathrm{A}}=\frac{\left(X_{i}^{A} / X_{t}^{A}\right)}{\left(X_{i}^{W} / X_{t}^{W}\right)}
$$

Where:

$\mathrm{RCA}_{\mathrm{i}}^{\mathrm{A}}$ : Revealed Comparative Advantage tuna of Aceh Province;

$X_{i}^{A}$ : Export value of tuna in Aceh Province (US\$);

$X_{t}^{A}$ : Total export value of Aceh Province (US\$);

$\mathrm{X}_{\mathrm{i}}^{\mathrm{W}}$ : World tuna export value (US\$);

$\mathrm{X}_{\mathrm{t}}^{\mathrm{W}}$ : Nilai total world exports (US\$).

\section{RESULTS AND DISCUSSION}

Tuna (yellowfin) is one of the commodities of fishing in Aceh Province and the presence of yellowfin tuna in Aceh waters is so large. yellowfin tuna fish has a higher selling 
point, nutritional content and demand. Tuna fish is not only in demand by the people of Aceh but also by other countries through export activities for these commodities. Tuna production fluctuates every year, following details of the development of tuna production in Aceh Province from 2011 to 2019.

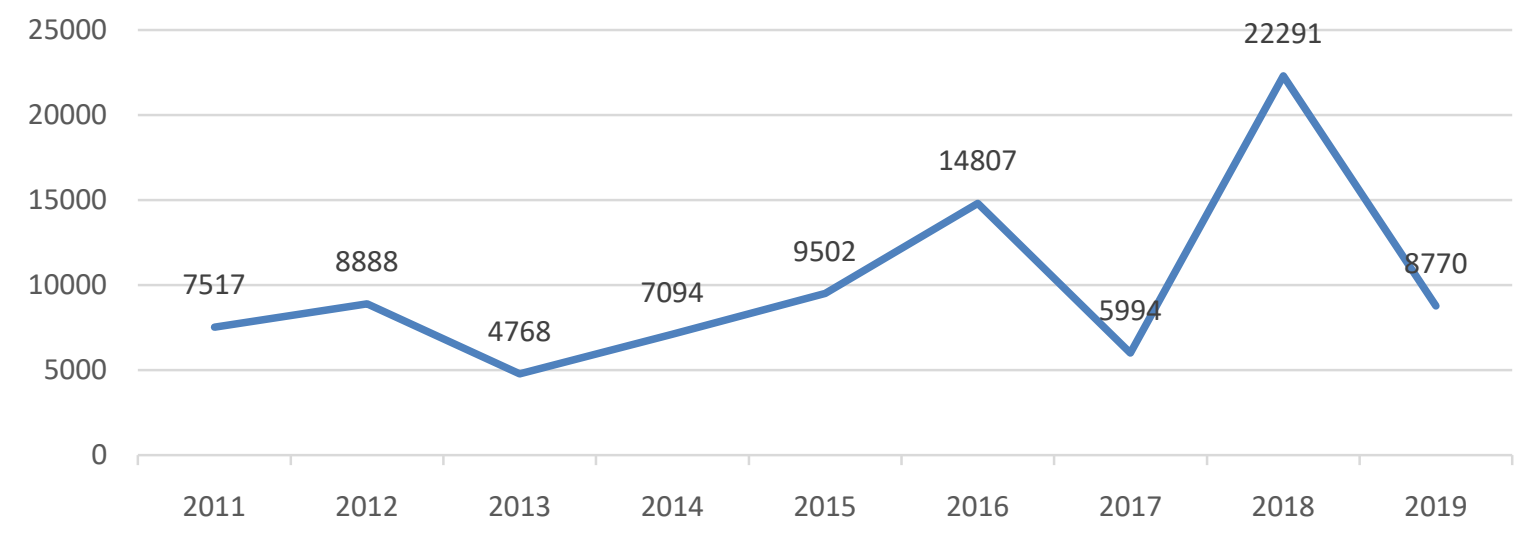

Figure 2 - Development of Tuna Fish Production in Aceh Province (Ton)

Based on Figure 2 above the production of tuna in Aceh Province have an average increase every year with an annual production of 9,959 tons. The highest tuna production occurred in 2018 with production reaching 22,291 tons. While the smallest production occurred in 2013, with a total production of 4,768 tons. Aceh tuna production during the nine years period experienced ups and downs (fluctuations). The declined in fishing yield (production) is due to indications of decrease in water quality (physical, chemical and biological), over fishing activities, and destructive fishing patterns (Ismail, 2018). However, the increase and decrease in the number of tuna production in Aceh is indicated due to the influence of fishing efforts and catching season (Aprianty, 2019).

As with production, the price of tuna has also fluctuated over the last nine years, namely 2011 to 2019 . The increase and decrease in fish prices are generally caused by seasonal factors which cause an imbalance between demand and supply of marine fish. During the fishing or harvest season, there is an oversupply so that prices tend to be cheap. Whereas in the dry season or fishing season occurs during the full moon, the catch decreases, this causes the price of fish to be expensive (Rahim, 2016). Beside that, the factors of taste and preference as well as bargaining position also influence the price of fish.

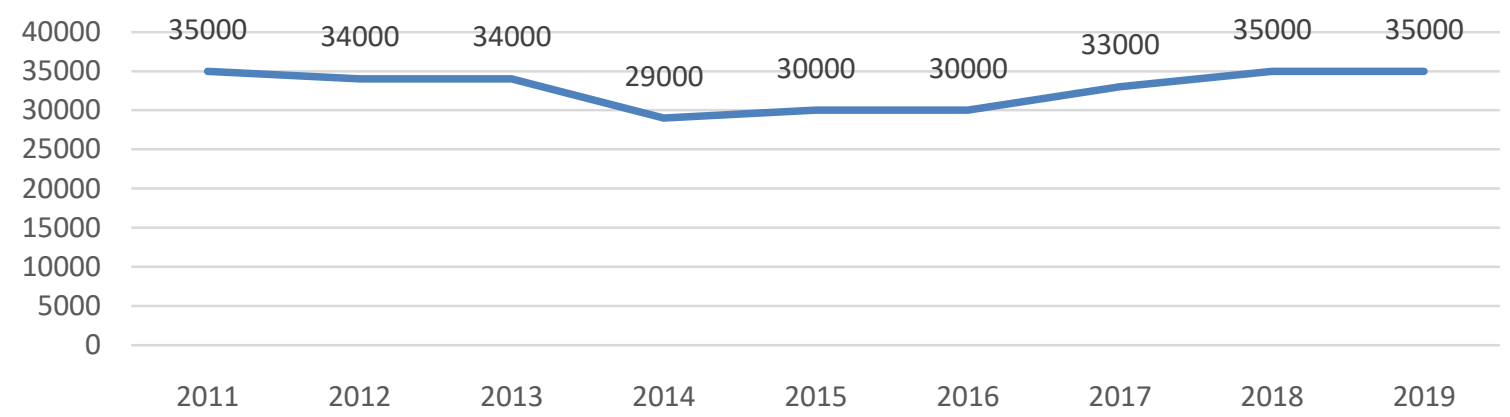

Figure 3 - Price of Tuna in Aceh Province $(\mathrm{Rp} / \mathrm{Kg})$

Based on Figure 3 above, the price of tuna in Aceh Province fluctuated from 2011 to 2019. The annual average price of fish is $\mathrm{Rp} 32,778$ per $\mathrm{kg}$. Figure 3 above shows the highest price for tuna is Rp 35,000 per $\mathrm{kg}$ and occurred in 2011, 2018 and 2019. While the lowest price occurred in 2014, with the price of tuna fish per $\mathrm{kg}$ of $\mathrm{Rp} 29,000$ per $\mathrm{kg}$. 
Tuna fish is one of the main export commodities of Aceh Province. In 2011 Aceh Province exported tuna for the first time in the international market. Tuna is mostly exported in the form of fresh fish and frozen fish, whose marketing is shown in several countries. During the last nine years, from 2011 to 2019, tuna in Aceh Province has been exported in six countries, namely Thailand, Hong Kong, Singapore, Japan, Korea and Malaysia. In Figure 4 below shows the development of tuna export volume in Aceh Province.

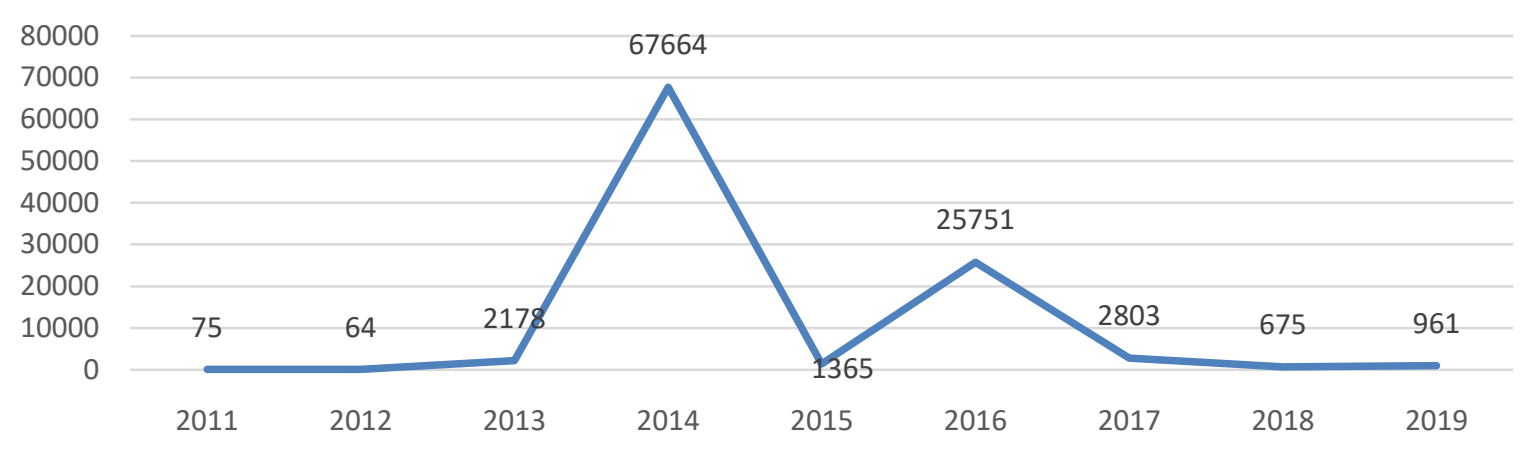

Figure 4 - The Export Volume of Tuna in Aceh Province (Kg)

In Figure 4 it can be seen that the amount of tuna in Aceh Province that exported to the international market fluctuated during 2011 to 2019. The highest number of exports occurred in 2014 with the total tuna exported was 67,664 kg. While 2011 and 2012 were the year that Aceh Province had the last amount of tuna export. The number of tuna exported in that year was only $75 \mathrm{~kg}$ and $64 \mathrm{~kg}$. Aceh Province tuna production, the export prices of tuna, exchange rates and GDP of importer countries are very influential on the number of tuna fish exported (Bramantya,2017). These factors can cause fluctuation in the number of export carried out.

The competitiveness of tuna export of Aceh Province based on comparative advantage was analyzed using RCA (Revealed Comparative Advantage) approach. RCA is measured based on the performance of tuna exports from Aceh Province to the total exports of all commodities of Aceh Province which are then compared to the performance of world tuna exports to the total exports of all world commodities. In the calculation, RCA can be interpreted if the share of tuna exports in Aceh Province in its total commodity exports is greater than the share of world tuna exports in total commodity exports then Aceh Province has a comparative advantage in tuna production and export, with indicators if the value of $\mathrm{RCA}$ is greater than $1(\mathrm{RCA}>1)$ then the tuna of Aceh Province is above the world tuna average. So Aceh Province has a comparative advantage and high competitiveness to tuna. If the value of $R C A$ is less than $1(R C A<1)$ the tuna fish of Aceh Province will below the world average. It means that Aceh Province does not have a comparative advantage and weak competitiveness towards tuna. The results of the analysis of the competitiveness of tuna fish in Aceh Province using the RCA approach can be seen in table 1 below.

Table 1 - The Competitiveness of Tuna in Aceh Province Based on Comparative Advantage

\begin{tabular}{|l|l|l|}
\hline Years & RCA index & Indicator \\
\hline 2011 & 0,007 & $\mathrm{RCA}<1$ \\
\hline 2012 & 0,004 & $\mathrm{RCA}<1$ \\
\hline 2013 & 0,268 & $\mathrm{RCA}<1$ \\
\hline 2014 & 6,822 & $\mathrm{RCA}>1$ \\
\hline 2015 & 1,454 & $\mathrm{RCA}>1$ \\
\hline 2016 & 23,887 & $\mathrm{RCA}>1$ \\
\hline 2017 & 2,435 & $\mathrm{RCA}>1$ \\
\hline 2018 & 0,375 & $\mathrm{RCA}<1$ \\
\hline 2019 & 0,506 & $\mathrm{RCA}<1$ \\
\hline Average & 3,973 & $\mathrm{RCA}>1$ \\
\hline
\end{tabular}

Source: BPS and Trade Maps, 2020 (processed). 
Based on Table 1, it can be seen that the average value of RCA is greater than 1, it shows that the tuna commodity of Aceh province has comparative advantages in the international market. Aceh Province had experienced weak competitiveness or did not have comparative advantage over tuna commodity in the international market in 2011-2013 and 2018-2019. The weak competitiveness of tuna fish in Aceh Province is thought because of the quality of tuna fish that are not suitable for export, such as containing histamine; other things are also caused by inadequate facilities such as the unavailability of cold storage used to accommodate exported tuna fish. In addition, transportation problems are also one of the causes of weak competitiveness of tuna exports of Aceh Province because of the unavailability of the fleet used to export directly to the destination country, so that the exported tuna fish must use an indirect fleet to the destination country, it makes the delivery of tuna fish to be slow and the delivery of tuna fish to the destination country will also be late, thus the quality of tuna fish exported will be decreased (Suhartanti, 2017). In addition, the weak competitiveness of tuna fish is also caused in 2011 Aceh Province has just started exporting tuna fish (BPS, 2011) so that the share of tuna exports in that year has not expanded which causes less demand for tuna fish. In that year Aceh Province only exported in Malaysia and Hong Kong.

In Table 1 shows that the average RCA index value is more than 1, it means that tuna in Aceh Province have a comparative advantage. Comparative advantage of tuna exports of Aceh Province is due to the performance of tuna export from Aceh Province towords total exports of Aceh Province is much greater than the export performance of world tuna export to the total world exports (UN Comtrade, 2020).

\section{CONCLUSION}

Based on the analysis using Revealed Comparative Advantage (RCA) method, it was obtained that Aceh Province's export tuna fish has comparative advantages in the international market. The comparative advantages that exist in tuna in Aceh Province is obtained because of the performance of Aceh Province's tuna to the total exports of Aceh Province are far greater than the performance of world's tuna to total world export.

\section{REFERENCES}

1. Apriyanti. 2019. Analysis of Yellowfin Tuna (Thunnus Albacares Fisheries Management in the Waters of North Aceh. ICONES.

2. Badan Pusat Statistik. 2011-2019. Produk Domestik Regional Bruto. BPS Provinsi Aceh.

3. Badan Pusat Statistik. 2011-2019. Statistik Perdagangan Luar Negeri. BPS Provinsi.

4. Bramantya, A. 2017. Analisis Faktor-Faktor Yang Mempengaruhi Ekspor Ikan Tuna Ke Negara Jepang dan Amerika Serikat Tahun 2005-2014. Universitas Brawijaya. Malang.

5. FAO. 2012. World Food and Agriculture. Statistical Pocketbook.

6. Ismail, M. 2018. Faktor-Faktor Penyebab Menurunnya Hasil Tangkapan Ikan dan Upaya Meningkatkan Fungsi Resevat Ikan Air Tawar. Balitbangda Kukar.

7. Kelautan dan Perikanan Provinsi Aceh. 2019. Profil Peluang Usaha dan Investasi. Dinas Kelautan dan Perikanan Aceh.

8. Rahim. Kurniawan, A.W. Hastuti, D.R.D. 2016. Analisis Faktor-Faktor Yang Mempengaruhi Fluktuasi Harga Ikan laut Segar di Sulawesi Selatan. Universitas Negri Makassar.

9. Suhartanti, P. D dan Darmono, N. 2017. Studi Penentuan Pelabuhan Utama Ekspor Ikan Tuna di Aceh. Seminar Nasional Pascasarjana (SNP) Unsyiah. Banda Aceh.

10. UN Comtrade. 2020. Ekspor Ikan Tuna Dunia. http://comtrade.un.org/data. Diakses Pada Tanggal 27 November 2020. 